\title{
The Legal Attribute of Civil Retrial Procuratorial Suggestion and the Perfection of Its System
}

\author{
Guo Wei* \\ Ph.D. Candidate of Collaborative Innovation Center of Judicial Civilization, China \\ University of Political Science and Law, Beijing100088, China \\ *Corresponding author e-mail: wss76123@163.com
}

\begin{abstract}
The civil retrial procuratorial suggestion is the legal supervision method officially established by the Civil Procedure Law. The main features are the same level supervision, case supervision, flexible supervision, etc. As an important supplement to the civil protest system, the legal effect should be positioned to trigger the court. The review procedure of the effective referee shall be initiated when the original judgment is "indeed wrong". In judicial practice, the number of civil retrial procuratorial suggestions has steadily increased, and it has been compared with the number of civil protest cases. But because the legislative provisions are very principled, the retrial procuratorial suggestions lack specifications in terms of scope of application, procedures, and styles of instruments, which affect their functions fully use. To improve the civil retrial procuratorial suggestion system, we should adhere to the modest principle of civil procuratorial supervision, the principle of limited retrial and the principle of litigation benefit. It is recommended that "the two high"(the Supreme People's Court and the Supreme People's Procuratorate) should issue special judicial interpretation as soon as possible, clarify the main disputed legal issues, standardize specific procedures, and strengthen data statistics and judicial disclosure.
\end{abstract}

KEYWORDS: civil, retrial procuratorial suggestions, legal attributes, system improvement

\section{Introduction}

In August 2012, the Standing Committee of the National People's Congress (NPC) wrote "procuratorial suggestions" into the Civil Procedure Law of the People's Republic of China, and the retrial procuratorial suggestions were upgraded to the legal supervision mode approved by legislation. When the civil procedure law was revised again in June 2017, the content of retrial procuratorial suggestions was not involved.For more than six years, as an important supplement to the protest 
system, the civil retrial procuratorial suggestion has played a greater role in resolving civil disputes, safeguarding the rights and interests of the parties, optimizing the allocation of judicial powers and improving the relevant working mechanism.However, because the relevant provisions of the civil procedure law are too principled, the supreme people's court and the supreme people's procuratorate (hereinafter referred to as "the two high") failed to issue a special judicial interpretation on handling the retrial procuratorial suggestions, and the procedures and standards for handling the retrial procuratorial suggestions have never been completely unified.At the same time, in the important theoretical and practical issues such as the legal orientation, supervision effectiveness, and handling procedures of the retrial procuratorial suggestions, there are still some differences in the academic circles, courts, and procuratorates, which have affected the full function of the civil retrial procuratorial suggestion system.In view of this,the paper tries to analyze the legal attribute, legislative status and operation of the civil retrial procuratorial Suggestions, and put forward some Suggestions on improving the specific system, in order to benefit the unified theoretical understanding and standardize judicial practice.

\section{The Evolution of Civil Retrial Procuratorial Suggestion}

Civil retrial procuratorial suggestion refer to local people's procuratorates at all levels who have made legally effective judgments or rulings in the people's courts at the same level, find out that there are retrial reasons prescribed by the Civil Procedure Law, or find that the mediation statement harms the interests of the state and the public, may make retrial procuratorial suggestions to the people's courts at the same level. The civil court initiates the retrial procedure to rectify itself as a way of legal supervision. The development of civil retrial procuratorial suggestions has gone through four stages.

\subsection{The "two high" each issued a normative document stage}

On September 30, 2001, the Supreme People's Procuratorate issued the "Rules for Handling Cases of Civil Administrative Protest Cases of the People's Procuratorate." Article 47 stipulates: "After the People's Procuratorate has agreed with the people's court at the same level to submit a procuratorial proposal to a case, if it meets the conditions for retrial, it may initiate a retrial procedure ex officio." On November 1, 2001, the Supreme People's Court issued the Minutes of the National Trial Supervision Work Symposium on Several Issues Concerning the Current Judicial Supervision Work. Article 17 stipulates that: The People's Procuratorate shall, in consultation with the people's court at the same level, propose procuratorial suggestions on the case. If the book meets the conditions for retrial, the retrial procedure may be initiated ex officio."According to the above two normative documents, the civil retrial procuratorial suggestions began to be promoted and applied at local procuratorates and courts. 
Academic Journal of Humanities \& Social Sciences

ISSN 2616-5783 Vol. 1, Issue 1: 72-83, DOI: 10.25236/AJHSS.040011

\subsection{The "two high" joint conference signature document stage}

On March 10, 2011, "two High" jointly issued "Several Opinions on the Implementation of Legal Supervision over Civil Trial Activities and Administrative Litigation (Trial)" (hereinafter referred to as the "Signature Document"), Article 7 stipulates: "Local People's Procuratorates at Various Levels Judgments, rulings, and mediations that meet the conditions stipulated in Articles 5 and 6 of these Opinions may be submitted to the people's court at the same level for retrial procuratorial decisions upon the decision of the procuratorial committee. After receiving the retrial procuratorial suggestions, the people's court shall conduct a review within three months and return the results of the review to the People's Procuratorate in writing."This is the first time that the "two high" officially used the concept of "civil retrial procuratorial suggestion". On the basis of earnestly summarizing the practical experience, the Signature Documents made principled provisions on the main issues such as the scope of application, procedures, and review period.

\subsection{The Standing Committee of the National People's Congress formally incorporates the civil retrial procuratorial suggestion into the legal stage}

In August 2012, the Standing Committee of the National People's Congress amended the Civil Procedure Law by adding the legal supervision mode of "procuratorial suggestions", which made the retrial procuratorial suggestions realize the transition from unilateral provisions and Signature Document to legislation.Article 208, paragraph 2, and Article 209 of the Civil Procedure Law are special provisions on "retrial procuratorial suggestions". Although the term "retrial procuratorial suggestions" is not explicitly used in the article, Wang Shengming (deputy director of the Law and Industry Committee of the Standing Committee of the National People's Congress) used the concept of "retrial suggestion" in the Note on the Amendment (Draft) of the Civil Procedure Law of the People's Republic of China at the 23rd Meeting of the Standing Committee of the Eleventh National People's Congress on October 24, 2011, which indicated that "retrial procuratorial suggestion" had been approved by the legislature.

\subsection{The "two high" judicial interpretation to make detailed provisions stage}

Because the relevant provisions of the Civil Procedure Law are very principled, the "two high" Signature Documents belong to the trial nature, and some provisions of the Signature Documents can not meet the needs of judicial practice, so the Supreme People's Procuratorate began to draft the "Provisions (Draft) on Several Questions Concerning the Handling of Procuratorial Suggestion Cases".However, due to the failure to reach agreement with the Supreme People's Court on a number of important issues, it has not been formally introduced.On November 18, 2013, the Supreme People's Procuratorate issued the "People's Procuratorate Civil Litigation Supervision Rules (Trial)", which stipulated some issues concerning the procuratorial organs' handling of retrial procuratorial suggestions.The Supreme 
People's Court has not yet issued a special judicial interpretation of the retrial procuratorial suggestions. At present, only a few provisions have been made in the newly revised Opinions on the Application of Several Questions of the Civil Procedure Law of the People's Republic of China , but the content is still relatively rough.On September 1, 2016, the Trial Supervision Division of the Supreme People's Court and the civil administrative procuratorial office of the supreme people's procuratorate repeatedly negotiated and issued the "Supreme People's Court Trial Supervision Division of the Supreme People's Procuratorate Civil Administrative Procuratorate on the handling of civil affairs in the name of the "two high" functional departments. Some of the matters recommended by the retrial procuratorial suggestions have been clarified, but the relevant provisions are still relatively general and the document has a lower level of effectiveness.

\section{Analysis of the Legal Attributes of Civil Retrial Procuratorial Suggestions}

The legal nature of the retrial procuratorial suggestions has been highly controversial. Some viewpoints hold that the civil prosecution suggestion is an effective way for the procuratorial organ to achieve comprehensive social security management, and it is a non-litigation supervision method that assists the procuratorial organ in achieving the purpose of legal supervision. Some people think that the procuratorial suggestion is only a work suggestion, and it should not be a supervisory measure. The retrial procuratorial suggestion is only a springboard to the same level of protest, and it is prepared for the defense of the same level in the future [1].This paper believes that the civil retrial procuratorial suggestion system is from scratch, from the trial of judicial practice to the formal establishment of legislation, from the low legal level to the high legal level.We should not only see that it belongs to the category of "procuratorial suggestion" as a whole, but also that it is obviously different from "general procuratorial suggestion", so it has its own relatively independent legal attributes.

\subsection{Civil retrial procuratorial advice is a statutory and independent way of legal supervision}

The Civil Procedure Law initially only stipulated protest as a way of procuratorial supervision. When it was revised in 2012, it added the way of supervision of procuratorial suggestions. In addition, in other litigation or nonlitigation legal supervision practices, there are also ways of supervision such as notice of correcting violations, procuratorial opinions, procuratorial letters, etc.The extension of procuratorial suggestions is very wide, including the supervision of judicial organs, administrative organs and other units. The supervision of judicial organs includes the supervision of litigation activities and the supervision of execution. The supervision of litigation activities can be divided into retrial procuratorial suggestions and general procuratorial suggestions.The purpose of supervision is to pursue the retrial of a case. After the court accepts the case, it examines whether or not it should be retried. The function of retrial procuratorial 
suggestion is obviously different from that of general procuratorial suggestion "improving work".Therefore, the civil retrial procuratorial suggestions have strong independence because of such factors as legislative confirmation, clear purpose of supervision, single object of supervision and wide scope of application. It is a specific way for procuratorial organs to exercise legal supervision power.

\subsection{The civil retrial procuratorial suggestion is positioned as an important supplement to the protest system}

According to the Civil Procedure Law before the revision in 2012, the local procuratorates at various levels did not have the power to directly supervise the retrial of the courts at the same level, and only the powers of the higher authorities to appeal to the procuratorate.After the retrial procuratorial suggestion is confirmed by the legislation, the procuratorate can directly supervise the effective judgment of the court at the same level, and together with the protest, it becomes the two major methods for legal supervision of the effective judgment.From the perspective of judicial power allocation, the legislation gives the procuratorate the direct supervision over the judgment of the courts at the same level, and strengthens the legal supervision functions of the local procuratorates, especially the grass-roots procuratorates.Judging from the types of legal supervision, the civil retrial procuratorial suggestions are relatively independent, enriching the way of legal supervision at the same level.Some scholars believe that the retrial procuratorial suggestion to achieve the diversification of civil prosecutorial supervision work [2].Judging from the trial distribution of cases, the appropriate diversion of litigation cases has been realized, enriching the number of cases in the municipal and county procuratorates and the middle and basic courts, and alleviating the pressure on the provincial inspection, the provincial high court and the "two high".From the perspective of the parties, it is conducive to seeking judicial relief nearby, which is conducive to the resolution of contradictions and disputes in the local area, and is conducive to further improving the efficiency of legal error correction.

\subsection{The retrial procuratorial suggestion can trigger the court's internal review procedure}

"Legal effectiveness is the way law exists and is the life of law" [3].The legal effect of the retrial procuratorial recommendation is one of the core elements of this system.The civil procedure law does not stipulate the legal effect of the retrial procuratorial suggestion. The Signature Document stipulates that “after the people's court receives the retrial procuratorial recommendation, it shall conduct the review within three months", and the newly revised judicial interpretation of the civil procedure law confirms this.This provision of the Signature Document and the judicial interpretation of the civil procedure law gives the retrial procuratorial suggestion "procedural coercive effect", that is, the retrial procuratorial suggestion cannot directly lead to the retrial procedure as if it were a protest, but it can be triggered after the court accepts it according to law. Court internal review process.It 
holds that retrial procuratorial suggestions are "suggestions for improving work", ignoring that the object of supervision is effective adjudication rather than a specific work. The purpose of supervision is to start retrial procedure, and it can trigger court review procedure, which is closely related to the opening of retrial procedure.It holds that retrial procuratorial suggestions should be transformed into "protest at the same level", ignoring that legislation is intended to enrich the way of "supervision at the same level" rather than create a "protest at the same level" procedure. Retrial procuratorial suggestions still belong to the category of "suggestion", "probable" rather than "order" and "necessity".

\section{The Appearance Characteristics of Civil Retrial Procuratorial Suggestions}

As a legal supervision system, the civil retrial procuratorial suggestion is unique in the Chinese legal system. There are no samples in the United States, Britain, Germany, Japan and other countries. Only in the Chinese legal system, the civil retrial procuratorial suggestions still have distinct characteristics and are distinguished from other similar legal systems.

\subsection{Supervision at the same level}

Local procuratorates at various levels may directly supervise the effective judgments and rulings made by the courts at the same level, instead of requesting the people's procuratorate at the next higher level to protest.That is to say, in addition to the "superior procuratorates protest against cases of lower courts" mode, the legal supervision method of "same level supervision" has been added.

\subsection{Case supervision}

The civil retrial procuratorial suggestion shall be based on the statutory grounds stipulated in the Civil Procedure Law. The goal is to recommend that the court initiate a retrial procedure for a particular case. It is a legal supervision of a specific case, not a specific type of case or the abstract supervision of a legal issue.

\subsection{Flexible supervision}

The retrial procuratorial suggestion is "supervised by the same level” compared with the protest, so its supervision effectiveness is weakened, and it does not necessarily lead to retrial of the case. Compared with the "rigid" supervision of the protest, the retrial procuring suggestion can be called "flexible" supervision. As a kind of non-litigation flexible legal supervision, civil procuratorial advice forms a useful complementarity with the protest system, forming a dualistic pattern of China's civil legal supervision system [4]. 


\subsection{The principle of filing}

The law has set limits and restrictions on the re-examination of procuratorial suggestions, that is, it requires that the re-examination and prosecution suggestions should be reported to the higher-level procuratorate for filing, and the higher-level procuratorate should supervise and guide them, so as to maintain the consistency of the legal awareness of the lower-level procuratorates, and reduce the arbitrariness in exercising the power of retrial procuratorial suggestion.

\subsection{The principle of the court corrects errors first}

In the design of the order of remedy for the effective judgment of "errors", the civil procedure law adopts the mode of "the court corrects errors first, the procuratorial supervision terminates later", and safeguards the priority remedy of the judicial power itself to the right of action. The party concerned shall not appeal to the procuratorial organ unless he has applied to the court for retrial and conforms to the statutory circumstances, otherwise the procuratorial organ shall not accept it.

\subsection{The principle of one-time legal supervision}

In order to solve the persistent problem of "endless final trial and repeated retrial", the Civil Procedure Law clearly stipulates that the parties shall not apply to the People's Procuratorate for procuratorial suggestions or protests again. At this time, the effective judgment shall be determined and the adjusted civil legal relationship will be stabilized.

\section{Empirical Investigation of Civil Retrial Procuratorial Suggestion}

According to the materials I have consulted, the civil retrial procuratorial suggestion system has made some achievements, and its frequency of use is relatively high. The number of civil administrative retrial procuratorial suggestion cases is equal to that of protest cases every year. The details are as follows.

Table 1 Statistical data of civil administrative protests and retrial procuratorial suggestions of procuratorial organs throughout the country [5]

\begin{tabular}{|c|c|c|c|}
\hline Year & Number of protest cases & Number of retrials procuratorial suggestion cases & Total \\
\hline $2008-2012$ & 55992 & 45823 & 101815 \\
\hline 2013 & & & 15538 \\
\hline 2014 & & & 9378 \\
\hline 2015 & 3548 & 3874 & 7422 \\
\hline 2016 & 3282 & 2851 & 6133 \\
\hline 2017 & & & $5520+$ \\
\hline $2013-2017$ & $20000+$ & 24000 & $44000+$ \\
\hline
\end{tabular}


ISSN 2616-5783 Vol. 1, Issue 1: 72-83, DOI: 10.25236/AJHSS.040011

However, there are still some problems in the operation, mainly in the following aspects.

\subsection{Civil retrial procuratorial suggestion of the first-instance referee are a large proportion}

Article 4 of the Signature Document stipulates that "the party's first-instance judgment and ruling that can be appealed shall file a complaint after the legal effect has occurred, and it shall state the reasons for not filing the appeal; if there is no justifiable reason, it shall not be accepted.” There are still many cases of prosecution suggestions or protests, and some provinces account for more than $50 \%$. What is the lack of recognition criteria for "reasonable reasons" for not appealing, how to review the lack of procedural norms, and the implementation of this provision is not in place.

\subsection{There is no restriction on the time limit for applying for retrial of procuratorial suggestions}

Article 209 of the Civil Procedure Law stipulates three situations in which a party may apply to the people's procuratorate for procuratorial advice. However, there is no provision for the parties to apply for procuratorial suggestions within a long period of time. In judicial practice, litigants often apply for procuratorial supervision over judicial documents that have been in effect for more than two years or even more. In many cases, procuratorial organs put forward retrial procuratorial suggestions accordingly, which makes effective judgments unstable for a long time and affects the orderly development of economy and society.

\subsection{The scope of application of retrial procuratorial suggestions and protests is not well understood}

The Civil Procedure Law stipulates that the retrial procuratorial suggestions and the protests can be submitted in exactly the same situation. It is difficult to grasp the circumstances and should propose retrial procuratorial suggestions, and in which cases should be brought to the protest. The current system does not have a clear relationship between the protests and the prosecutorial suggestions, which leads to ambiguity in the identification of the nature of the system and the positioning of core functions [6]. Although the "People's Procuratorate Civil Litigation Supervision Rules (Trial)" provides for the "retrial procuratorial suggestions can be put forward" and "protest should be submitted", the application of the two in judicial practice is still difficult to distinguish, only by the prosecution Choose according to the circumstances of the case. 
Academic Journal of Humanities \& Social Sciences

ISSN 2616-5783 Vol. 1, Issue 1: 72-83, DOI: 10.25236/AJHSS.040011

\subsection{The review criteria for retrial procuratorial suggestions are not uniform}

When the court examines the civil retrial procuratorial suggestions, some of them are full-case review, some are only for the cause of procuratorial suggestions; some are only for written review without contacting the parties, and some will notify the parties to submit evidence and defense opinions. On the criteria for initiating retrial, some believe that the re-examination should be initiated in accordance with the standards of ex officio review, and the retrial should be initiated after retrial. Some believe that the retrial review criteria should be followed, and that there is a statutory retrial. A retrial should be initiated and whether the change is based on the circumstances of the retrial.

\section{5 "Follow-up supervision" and "limited retrial" face conflicts}

Article 7 of the Signature Document stipulates that if the procuratorate considers that the court's decision not to retry the procuratorial suggestion is improper, it shall submit a protest to the people's procuratorate at a higher level. Procuratorial organs generally call this "follow-up supervision" of higher procuratorates, which is also widely used in practice. "Follow-up supervision" will form two or more times of procuratorial supervision on the same effective judgment, which is in conflict with the original intention of the system design of "limited retrial". If "follow-up supervision" is overused, it will easily lead to the rebound of "repeated appeals, endless final appeal".

\section{The Perfect Path of the Civil Retrial Procuratorial Suggestion System}

At present, there are some problems in the system of procuratorial suggestions for civil retrial, some of which are due to the divergence of concepts, some of which are due to the lack of top-level design at the "two high" level, and some of which are due to the inadequate implementation of existing legal provisions. To improve the system of procuratorial suggestions for civil retrial, we should not only follow the general legal principles to resolve the differences in understanding, but also clarify the power boundaries of procuratorates and courts, and fully protect the litigation rights of the parties, so as to build a clear, standardized and efficient legal system. In the pursuit of value, we should adhere to the following three principles.

\subsection{Adhering to the principle of modesty and restraint in civil procuratorial supervision}

The litigation right evolved from the private right of the parties has the characteristics of equality and the right to dispose according to law [7]. In civil litigation, the parties have the right to punish their substantive and procedural rights, which is the requirement of autonomy of will in the field of private law. When the parties do not apply for procuratorial supervision, if it does not involve the interests 
of the state and the public, the procuratorial organs are generally not suitable to intervene in private rights disputes, and the application conditions of the so-called "re-inspection procuratorial suggestions for ex officio" should be strictly limited. When the parties seek procuratorial supervision for exercising their own remedy means, the procuratorial organs should strictly examine the reasons why they have not exhausted the remedy means of judicial power. The procuratorial organs should not exercise legal supervision over the first instance effective cases without "legitimate reasons" and without appeal.

\subsection{Adhering to the principle of limited retrial}

The "Decision of the Central Committee of the Communist Party of China on Comprehensively Promoting Major Issues in Governing the Country According to Law" points out that "retrial focuses on solving errors according to law and safeguarding the authority of judges". The Civil Procedure Law "preliminarily established a limited retrial system with Chinese characteristics" and established a "limited retrial" of the " $3+1$ " model at the institutional level [8]. The result of this amendment has been generally recognized by all parties, but it is easy to be broken by the "follow-up supervision" system and re-emerge the problem of "repeated retrial". "Although the procuratorate has no final jurisdiction over retrial cases, if the number of counterclaims is not limited, it may protest the same case many times, affecting the stability and authority of the judiciary, at the same time aggravating the friction between the two courts of law and procuratorate, which is not conducive to the parties'interest judgment." [9]The procedural value of "limited retrial" should be fully valued and effectively maintained. The legal supervision of procuratorial organs should be restrained. Generally, the principle of "one-time procuratorial supervision" should be taken as the principle. The applicable standard of "follow-up supervision" should be clear, clear and strict. At the same time, the court retrial procedure should effectively correct errors according to law, dare to correct errors, effectively correct errors, safeguard the authority of the judgment, and highlight judicial justice.

\subsection{Adhering to the principle of procedural benefits}

The retrial procuratorial suggestion is "supervision at the same level", which is more convenient for the parties to seek judicial relief and reduce the burden of litigation. We should continue to improve the effectiveness of the retrial procuratorial suggestion on this basis. The time limit for handling retrial procuratorial suggestions should be shorter than that for protesting. The courts and procuratorates should complete the process within the statutory time limit. The time limit for the parties to apply for procuratorial supervision should also be restricted. The judicial cost and the parties'appeal cost should be reduced as much as possible to find the best balance between fairness and efficiency.

As far as the specific system is concerned, the following aspects should be done well.

Published by Francis Academic Press, UK 
Academic Journal of Humanities \& Social Sciences

ISSN 2616-5783 Vol. 1, Issue 1: 72-83, DOI: 10.25236/AJHSS.040011

\subsection{Clearly define the main legal issues such as review criteria}

The main disputed issues should be resolved and clarified as soon as possible on the basis of a unified value orientation. To clarify the scope of application of protest and retrial procuratorial suggestions, to realize the functional distinction between them, and to give full play to their respective values.As for the standard of starting retrial in civil retrial cases recommended by the procuratorate, because the cases have generally been applied for retrial review, it should be carried out in accordance with the "indeed wrong" standard stipulated in Article 198 of the Civil Procedure Law, and the judgment should be changed without special circumstances after starting retrial.The issue of trial procedure after retrial may be referred to the procedure of "court retrial according to its authority".The scope of the trial is generally based on the legal reasons involved in the retrial procuratorial suggestions, clarifying the petitioner's request for retrial, in order to achieve the completion of the case, the scope of the trial may be expanded appropriately within the retrial proceedings request if necessary.For the scope of application of "follow-up supervision", it is should not easy to "follow-up supervision" except for cases involving imbalance of major interests or typical legal significance, and "follow-up supervision" should be limited to one time.As for the time limit for the parties to apply for retrial of procuratorial suggestions or protests from the procuratorate, it is not appropriate to remain in a blank state for a long time. The necessary time limit should be set to urge the parties to exercise their rights in time. It is suggested that the general time limit for the parties to apply for retrial from the court, namely six months, be taken as reference.

\subsection{Develop relatively independent procedures}

The retrial procuratorial suggestions are different from the general procuratorial suggestions and protests. A set of relatively independent and complete procedures should be formulated and stipulated in the form of specialized judicial interpretations.The main links of handling retrial procuratorial suggestions should include the acceptance, examination, decision, putting forward procuratorial suggestions, serving them to the parties, and the acceptance, examination, reply, initiation of retrial and notification of the parties to respond to the lawsuit by the court.Each link should be clear about the subject of responsibility, the operation process and the processing time limit.We should unify and standardize the form of legal documents for civil retrial procuratorial suggestions, especially strengthen the reasoning of the suggestions for civil retrial procuratorial suggestions, fully elaborate the facts and reasons of whether or not retrial should be conducted, and not simply quote legal provisions to draw conclusions.

\subsection{Strengthen the openness of civil retrial procuratorial suggestions}

Civil retrial procuratorial suggestion is one of the ways in which people's courts and people's procuratorates exercise public power. The exercise of power should be 
supervised. In addition to involving state secrets, commercial mechanisms and personal privacy, relevant legal documents should be made public to the society through the Internet, in order to protect the right to know and participate in the parties.At present, the information about the number of receipts of civil retrial procuratorial suggestions has not been disclosed in detail, which makes it difficult to evaluate the actual effect of civil retrial procuratorial suggestions. The judicial and statistical departments of the people's courts and procuratorates shall incorporate retrial procuratorial suggestions into their statistical calibre and regularly analyze and publish them, comprehensively and objectively reflect the operation of retrial procuratorial suggestions, and guide the whole society to understand retrial procuratorial suggestions so as to give full play to their functions.

\section{References}

[1] Sun Jiarui: "Several Issues Concerning the Procuratorial System of the New Civil Procedure Law", in Journal of National Prosecutors College, Vol. 22, No. 2.

[2] See Fan Weiguo: "Research on the Practice of Civil Retrial Prosecution suggestions - Analysis Based on Sample Data", Journal of Wuhan University of Technology (Social Science Edition) November 2017 Volume 30, Issue 6.

[3] Zhou Yongkun: Jurisprudence, Law Press, 2004 edition, p. 101.

[4] Han Jingru: "Civil Procura suggestion - to Civil Protest Perspective of Relationship Coordination, in Journal of Southwest University of Political Science and Law, 2013, No. 1.

[5] Data source is the work report of the Procurator-General of the Supreme People's Procuratorate at the plenary session of the National People's Congress from 2013 to 2018. Civil and administrative cases are not distinguished. Some annual data are vacant, and the chart shows a blank.

[6] Pan Jianfeng and Han Jingru, New Issues and New Consciousness: Challenges to Civil Trial in the Revision of Civil Procedure Law", 11 Law Application, 2012, P. 51.

[7] Editor-in-chief Wang Hongyi, etc.: Judicial Reform and Improvement of Civil Procedure Supervision System], Xiamen University Press, 2010, P. 250.

[8] Jiang Bixin, Sun Xiangzhuang and Wang Chaohui: Lecture on Judicial Supervision Procedure of New Civil Procedure Law, Law Press, 2012, P. 10. "3+1" model refers to a civil case, after first instance, second instance, retrial (or trial) by the court, and then protest by the procuratorate or put forward retrial procuratorial suggestions, the proceedings will be terminated, and the parties may not appeal for the final judgment.

[9] Tang Weijian: On the Improvement of the Civil Protest System, in the "People's Procuratorate", 2007, No. 9.

\section{Published by Francis Academic Press, UK}

